J. Dairy Sci. 95:1323-1336

http://dx.doi.org/10.3168/jds.2011-4744

(C) American Dairy Science Association ${ }^{\circledR}$, 2012. Open access under CC BY-NC-ND license.

\title{
Effects of monensin on metabolic parameters, feeding behavior, and productivity of transition dairy cows
}

\author{
C. R. Mullins, ${ }^{\star}$ L. K. Mamedova, ${ }^{\star}$ M. J. Brouk, ${ }^{\star}$ C. E. Moore,† H. B. Green, $†$ K. L. Perfield, † J. F. Smith, ${ }^{\star}$ \\ J. P. Harner, $\neq$ and B. J. Bradford ${ }^{\star 1}$ \\ *Department of Animal Sciences and Industry and \\ ‡Department of Biological and Agricultural Engineering, Kansas State University, Manhattan 66506 \\ †Elanco Animal Health, Greenfield, IN 46140
}

\section{ABSTRACT}

The effects of monensin on transition cow metabolism may be dependent on modulation of feeding behavior, rumen $\mathrm{pH}$, and expression of key metabolic genes. Multiparous Holstein cows were used to determine the effects of monensin $(400 \mathrm{mg} / \mathrm{cow}$ daily) on these variables. Cows were randomly assigned, based on calving date, to control or monensin treatments $(\mathrm{n}=16$ per treatment) $21 \mathrm{~d}$ before their expected calving date, and cows remained on treatments through $21 \mathrm{~d}$ postpartum. Feeding behavior and water intake data were collected daily. Liver biopsies were conducted after assessing $\mathrm{BCS}$ and $\mathrm{BW}$ on $\mathrm{d}-21,-7,1,7$, and 21 relative to calving for analysis of triglyceride (TG) content as well as mRNA abundance of cytosolic phosphoenolpyruvate carboxykinase, carnitine palmitoyltransferase 1a, and apolipoprotein B. Blood samples were collected 21, 7, and $4 \mathrm{~d}$ before expected calving and 1 (day of calving), $4,7,14$, and $21 \mathrm{~d}$ postpartum for nonesterified fatty acid, $\beta$-hydroxybutyrate, glucose, insulin, and haptoglobin analyses. Ruminal $\mathrm{pH}$ was collected every $5 \mathrm{~min}$ on d 1 through 6 postpartum via a wireless indwelling probe. On d 7 postpartum, a caffeine clearance test was performed to assess liver function. Data were analyzed using mixed models with repeated measures over time. Monensin decreased mean plasma $\beta$-hydroxybutyrate (734 vs. $616 \pm 41 \mu M)$ and peak concentrations $(1,076$ vs. $777 \pm 70 \mu M$ on d 4 postpartum). Monensin also decreased time between meals prepartum (143 vs. 126 $\pm 5.0 \mathrm{~min})$ and postpartum (88.8 vs. $81.4 \pm 2.9 \mathrm{~min})$, which was likely related to a smaller ruminal $\mathrm{pH}$ standard deviation in the first day after cows changed to a lactation ration (0.31 vs. $0.26 \pm 0.015)$. Monensin also increased liver mRNA abundance of carnitine palmitoyltransferase $1 \mathrm{a}(0.10$ vs. $0.15 \pm 0.002$ arbitrary

Received July 19, 2011.

Accepted October 26, 2011.

${ }^{1}$ Corresponding author: bbradfor@ksu.edu units), which corresponded to a slower rate of liver TG accumulation from $\mathrm{d}-7$ to +7 (412 vs. $128 \pm 83 \mathrm{mg}$ of $\mathrm{TG} / \mathrm{g}$ of protein over this time period). No significant effects of monensin supplementation were observed on milk production, liver cytosolic phosphoenolpyruvate carboxykinase, apolipoprotein B, plasma nonesterified fatty acid, glucose, insulin, or haptoglobin. No effects on disease incidence were detected, but sample size was small for detecting such effects. Overall, results confirm that the effects of monensin on transition cows extend beyond altered propionate flux.

Key words: monensin, transition cow, liver function, rumen $\mathrm{pH}$

\section{INTRODUCTION}

The weeks surrounding parturition are a critical time in the life cycle of a high-producing dairy cow. During this period, cows make many metabolic adjustments to support the transition from pregnancy to lactation. Furthermore, dairy cows produce milk in excess of their ability to consume energy, resulting in a period of negative energy balance in early lactation (Grummer, 1995). In recent years, monensin has been used to help mitigate the effects of negative energy balance, presumably by promoting ruminal production of glucogenic precursors (Duffield et al., 2008a,c).

Under normal physiological conditions, monensin alters ruminal digestion in a manner that augments propionate production rate and concentration in the rumen (Van Maanen et al., 1978). Greater propionate supply leads to increased hepatic gluconeogenesis (Aiello and Armentano, 1987), which could improve the overall energetic balance of the transition cow. Thus, an increased supply of glucose is often assumed to be the primary benefit of monensin supplementation. Observations of Sauer et al. (1989) support the hypothesis that monensin decreases the acetate:propionate ratio in transition cows. In contrast, when propionate kinetics were measured during the periparturient period, monensin did not affect ruminal propionate production (Markantonatos et al., 2009). Some studies have ob- 
served monensin to have beneficial effects on plasma lipids or ketones with no effect on plasma glucose concentration (Sauer et al., 1989; Petersson-Wolfe et al., 2007); in fact, one group even reported a tendency for decreased glucose concentration (Stephenson et al., 1997). This evidence suggests that the beneficial effects of monensin likely extend beyond gluconeogenic flux, and may even be independent of changes in gluconeogenesis.

Transition cow health is directly linked to DMI, partly because negative energy balance is not as severe in early lactation cows with higher intakes (Bertics et al., 1992). Recent transition cow research indicates a beneficial effect of monensin on the postpartum DMI curve (Shah et al., 2008) or overall DMI (Schroeder et al., 2009), but feeding behavior was not measured in either study. Research from feedlot cattle suggests dietary monensin could modulate intake patterns, thus decreasing dramatic changes in rumen $\mathrm{pH}$ while cattle are adapting to a high-energy diet (Stock et al., 1995; Nagaraja et al., 1997). Furthermore, data obtained from midlactation cows subjected to SARA indicates that administering monensin in feed increases meal frequency during the challenge and recovery periods (Lunn et al., 2005). The hypothesis that monensin affects transition cow rumen $\mathrm{pH}$ has not been extensively investigated. Monensin administered through a controlled-release capsule increased transition cow rumen pH (Green et al., 1999), but these data must be interpreted with caution because ruminal samples were collected using an esophageal tube. Research conducted using indwelling probes to measure $\mathrm{pH}$ showed no difference between monensin supplemented cows and control cows (Mutsvangwa et al., 2002; Fairfield et al., 2007), but Mutsvangwa et al. (2002) only had 3 animals per treatment and Fairfield et al. (2007) used a controlled-release capsule, which may not modulate intake as much as dietary monensin. Furthermore, neither of these studies examined differences in variance of rumen $\mathrm{pH}$.

The primary objectives of this study were to determine the effects of monensin on transition cow feeding behavior and metabolic parameters. The secondary objectives were to assess the effects of monensin on ruminal $\mathrm{pH}$ and productivity of transition cows.

\section{MATERIALS AND METHODS}

All experimental procedures were approved by the Institutional Animal Care and Use Committee at Kansas State University.

\section{Design and Treatments}

Thirty-two multiparous Holstein transition cows from the Kansas State University Dairy Cattle Teach- ing and Research Facility (Manhattan) were used in a randomized complete block design. Cows were blocked by expected calving date (16 blocks) and randomly assigned within block to 1 of 2 treatments $(\mathrm{n}=16$ cows per treatment) $21 \mathrm{~d}$ before their expected calving date. Cows remained on their respective treatments through $21 \mathrm{~d}$ postpartum. The treatment group received monensin (Rumensin; Elanco Animal Health, Greenfield, IN) as a top-dress at a rate of $400 \mathrm{mg} / \mathrm{cow}$ per day, and the control group received no monensin for the duration of the study. Cows were dried off an estimated $45 \mathrm{~d}$ before calving. Monensin was excluded from the far-off dry cow ration to help ensure that no cows entering the study were influenced by prior monensin exposure. Cows entered the study from January to June 2010.

Monensin was premixed into a ground corn carrier and $0.91 \mathrm{~kg}$ of the premix was offered daily to each cow in the treatment group. Monensin treatments were administered by top dressing and manually mixing the premix into the upper $33 \%$ of each TMR once per day. The ground corn carrier was top dressed to the control cows at the same rate in the same manner. The monensin dose was selected based on previous research (Schroeder et al., 2009) and approached the maximum FDA-approved label dose for dry cows of $410 \mathrm{mg} / \mathrm{cow}$ per day. Diets were formulated to meet or exceed NRC (2001) requirements (Table 1). Samples of all dietary ingredients were collected weekly and stored at $-20^{\circ} \mathrm{C}$. Upon study completion, feed ingredients were composited into bimonthly samples for wet chemistry analysis of CP, ADF, NDF, ether extract, and ash by Dairy One Forage Laboratory (Ithaca, NY).

\section{Management of Cows and Data Collection}

Cows were dried off and moved into a freestall pen approximately $45 \mathrm{~d}$ prepartum where cows received a low-energy diet $(\approx 1.35 \mathrm{Mcal} / \mathrm{kg})$ containing no monensin. Dry cows were moved into the maternity barn approximately $1 \mathrm{wk}$ before starting the study. Cows were allowed ad libitum access to the designated treatment rations by an electronic gating system (Roughage Intake System; Insentec B.V., Marknesse, the Netherlands), 1 cow assigned per gate. After parturition, cows were moved into a tie-stall facility where they remained through $21 \mathrm{~d}$ postpartum. Individual feed bunks in the tie-stall facility were suspended from load cells and bunk weight was monitored continuously by computer. Feed weights and times were stored before and immediately after any deviation in bunk weight. Dry cows were fed twice daily (0800 and $1530 \mathrm{~h}$ ) to accommodate the capacity of the feeding system used prepartum, and lactating cows were fed once daily $(1500 \mathrm{~h})$ to minimize the time during which feeding 
Table 1. Ingredient and nutrient composition of diets

\begin{tabular}{|c|c|c|}
\hline Diet composition & Prepartum & Postpartum \\
\hline \multicolumn{3}{|l|}{ Ingredient ( $\%$ of DM) } \\
\hline Corn silage & 30.3 & 34.0 \\
\hline $\mathrm{WCGF}^{1}$ & 19.6 & 21.5 \\
\hline Prairie hay & 39.7 & - \\
\hline Alfalfa hay & - & 16.6 \\
\hline Cottonseed & - & 6.7 \\
\hline Corn grain ${ }^{2}$ & 6.5 & 12.4 \\
\hline Soybean meal 48 & 4.1 & - \\
\hline Expeller soybean meal & - & 7.1 \\
\hline Micronutrient premix ${ }^{3,4}$ & 0.3 & 2.8 \\
\hline \multicolumn{3}{|l|}{ Nutrient (\% of DM) } \\
\hline DM (\% as-fed) & 57.2 & 54.2 \\
\hline $\mathrm{CP}$ & 13.1 & 17.3 \\
\hline $\mathrm{ADF}$ & 28.4 & 19.7 \\
\hline $\mathrm{NDF}$ & 49.9 & 36.0 \\
\hline $\mathrm{NFC}$ & 35.5 & 38.0 \\
\hline Ether extract & 3.4 & 5.0 \\
\hline Ash & 6.9 & 8.8 \\
\hline $\mathrm{NE}_{\mathrm{L}}^{5}(\mathrm{Mcal} / \mathrm{kg})$ & 1.58 & 1.68 \\
\hline
\end{tabular}

${ }^{1}$ Wet corn gluten feed (Sweet Bran; Cargill Inc., Blair, NE).

${ }^{2} \mathrm{~A}$ portion of the corn grain $(0.91 \mathrm{~kg} / \mathrm{cow}$ daily $)$ served as the topdress carrier for $400 \mathrm{mg}$ of monensin (Rumensin; Elanco Animal Health, Greenfield, IN) for supplemented cows. The same amount of corn alone was top-dressed for control cows.

${ }^{3}$ Prepartum premix consisted of $42.6 \%$ vitamin E premix, $11.9 \%$ Se premix, $11.6 \%$ trace mineral salt, $10.8 \%$ limestone, $9.71 \%$ vitamin $\mathrm{A}$ premix, $6.47 \%$ 4-plex, $4.31 \%$ vitamin $\mathrm{D}$ premix, $2.17 \%$ magnesium oxide, and $0.53 \%$ ethylenediamine dihydroiodide.

${ }^{4}$ Postpartum premix consisted of $48.4 \%$ limestone, $27.3 \%$ sodium bicarbonate, $12.6 \%$ trace mineral salt, $6.04 \%$ magnesium oxide, $2.33 \%$ 4-plex, $1.51 \%$ Se premix, $1.16 \%$ vitamin E premix, $0.46 \%$ vitamin A premix, $0.21 \%$ vitamin D premix, and $0.03 \%$ ethylenediamine dihydroiodide.

${ }^{5}$ Estimated according to NRC (2001).

behavior could not be recorded. All feeding activity, including meal length and size, were recorded electronically. As-fed feed intake of each cow was recorded on a daily basis. As-fed ration consumption was adjusted for DM content for determination of meal and daily DMI. Dry matter percentage was determined weekly for the corn silage and bimonthly for each concentrate ingredient; these values were used to determine ration DM for each week. Water was offered ad libitum, and individual water consumption was also recorded daily throughout the study. During summer months, the maternity barn and tie-stall facility were both cooled using evaporative pads.

Cows were milked 3 times daily in a milking parlor, and milk yields were recorded at each milking. Milk samples were collected from each milking beginning at 4 DIM and continuing through 21 DIM. Samples were analyzed for concentrations of fat, true protein, lactose (B-2000 Infrared Analyzer; Bentley Instruments Inc., Chaska, MN), urea nitrogen (MUN spectrophotometer; Bentley Instruments Inc.), and somatic cells (SCC 500, Bentley Instruments Inc.; Heart of America
DHIA, Manhattan, KS). Data from individual milkings were averaged by cow-day, using a statistical model to account for the random effect of milking. Energycorrected milk yield was calculated as: $0.327 \times$ milk yield $+12.86 \times$ fat yield $+7.65 \times$ protein yield (Dairy Records Management Systems, 2010). Solids-corrected milk production was calculated as: $12.3 \times$ fat yield + $6.56 \times \mathrm{SNF}$ yield $-0.0752 \times$ milk yield $($ Tyrrell and Reid, 1965).

Body weight was measured $2 \mathrm{~h}$ before feeding on $\mathrm{d}$ -21 and -7 relative to expected calving, and on $\mathrm{d} 1$, 7 , and 21 postpartum. Immediately after BW was obtained, liver samples were collected via needle biopsy. For collection of liver tissue, an area spanning the tenth and eleventh ribs was shaved, aseptically prepared, and anesthetized with $3.5 \mathrm{~mL}$ of subcutaneous lidocaine hydrochloride (Agri Laboratories Ltd., St. Joseph, MO). After 5 min, a \#10 blade (Feather Safety Razor Co. Ltd., Kita-Ku, Osaka, Japan) was used to make a stab incision into the body wall. A 14-gauge $\times 15 \mathrm{~cm}$ biopsy needle (SABD-1415-15-T; US Biopsy, Franklin, IN) was inserted through the incision and $200 \mathrm{mg}$ of tissue was collected (a total of 10 biopsies). Liver samples were snap frozen in liquid nitrogen immediately after collection, and then stored at $-80^{\circ} \mathrm{C}$ until subsequent analysis. Blood samples were collected from the coccygeal vessels after each biopsy and also $2 \mathrm{~h}$ before feeding on $\mathrm{d}-4$ relative to expected calving date and on $\mathrm{d}$ 4 and 14 postpartum. Approximately $14 \mathrm{~mL}$ of blood was collected into 2 tubes, one containing potassium EDTA and the other containing potassium oxalate with sodium fluoride as a glycolytic inhibitor (Vacutainer; Becton, Dickinson and Co., Franklin Lakes, NJ). Blood samples were centrifuged at 2,000 $\times g$ for $10 \mathrm{~min}$ immediately after sample collection, and plasma was collected and frozen at $-20^{\circ} \mathrm{C}$ until subsequent analysis of glucose, NEFA, BHBA, insulin, and haptoglobin concentrations. Body condition score was evaluated by 3 trained investigators on the same day $( \pm 1 \mathrm{~d})$ as BW and liver sample collections.

Indwelling ruminal $\mathrm{pH}$ probes (Rumen Sensors; Kahne Ltd., Auckland, New Zealand) were delivered to the rumen as an oral bolus after liver biopsy on $\mathrm{d} 1$ postpartum. These probes measured rumen $\mathrm{pH}$ every 5 min and used a radio frequency to transmit this data to a computer. Electronic data were collected in real time and were also stored on the probe. Stored data were downloaded during the biopsy on $\mathrm{d} 7$ to ensure collection of all recorded data. Measurement of rumen $\mathrm{pH}$ was limited to the first 7 DIM because of concern about drift in $\mathrm{pH}$ measurements from probes remaining in situ for more than $7 \mathrm{~d}$. Probes removed from 2 cows (cannulated for previous studies) on $\mathrm{d} 7$ postpartum generated $\mathrm{pH}$ values of 6.94 and 6.96 in $\mathrm{pH} 7.0$ buffer 
and 4.01 and 3.97 in $\mathrm{pH} 4.0$ buffer, suggesting that data analyzed here were valid.

Liver function was assessed using an in vivo caffeine metabolism test on d 7 postpartum (Lakritz et al., 2006). To conduct this test, jugular catheters (\#1411; Mila International, Erlanger, KY) were inserted and caffeine was administered as caffeine-sodium benzoate (C4144; Sigma-Aldrich Co., St. Louis, MO) in a sterile pyrogen-free normal saline solution (25 $\mathrm{mg}$ of caffeine/ $\mathrm{mL}$ of solution). Caffeine was infused intravenously in a bolus dose at the rate of $1 \mathrm{mg}$ of caffeine $/ \mathrm{kg}$ of $\mathrm{BW}$, and the $\mathrm{d} 7$ postpartum BW was used to calculate the amount of caffeine to infuse. Caffeine infusions were initiated at feeding time. Blood samples were collected immediately before infusion and at 30-min intervals for $180 \mathrm{~min}$ following infusion using disposable $5-\mathrm{mL}$ syringes. Blood was immediately transferred to a tube containing potassium EDTA (Vacutainer; Becton, Dickinson and Co.). Plasma was collected as described above and frozen at $-20^{\circ} \mathrm{C}$ until analysis. Catheter patency was maintained by flushing with $6 \mathrm{~mL}$ of sterile $3.5 \%$ sodium citrate solution following each collection.

Facilities and equipment were observed daily for abnormalities. Postpartum cows (and prepartum cows with abnormalities) underwent a health inspection daily, including monitoring for urine ketones (ReliOn ketone test strips; Bayer Healthcare LLC., Mishawaka, IN) and rectal temperature. Health records were kept throughout the study to register the incidence of ketosis, left displaced abomasum, retained placenta, metritis, milk fever, lameness, and other abnormalities. Ketosis was defined as a urine ketone concentration $>80 \mathrm{mg} /$ $\mathrm{dL}$, or urine ketone concentrations $>40 \mathrm{mg} / \mathrm{dL}$ for 2 or more consecutive days. Mastitis was defined as an SCC greater than 200,000 at any milking after d 3 (Dohoo et al., 2011). Other diseases were diagnosed according to definitions established by Kelton et al. (1998). If cows displayed signs of any disorder described they were treated according to on-site standard operating procedures. Cows were removed from the study if they were diagnosed with a displaced abomasum $(\mathrm{n}=3)$ or severe lameness $(n=1)$. Data obtained from these cows before removal from the study were included in all analyses. Cows diagnosed with a displaced abomasum were removed on d 7 (control), 8 (monensin), and 13 (control) postpartum, respectively. The cow removed for lameness issues was removed on d 7 (control) postpartum.

\section{Liver and Plasma Analyses}

Approximately $20 \mathrm{mg}$ of liver was placed in $500 \mu \mathrm{L}$ of chilled phosphate-buffered saline ( $\mathrm{pH} 7.4)$ and homogenized. The homogenate was centrifuged at 2,000 $\times g$ for $10 \mathrm{~min}$ at $4^{\circ} \mathrm{C}$ and $100 \mu \mathrm{L}$ of the supernatant was then removed for free glycerol and total protein analysis. Triglyceride (TG) content was measured using a method adapted from Starke et al. (2010). The remaining liver homogenate was incubated with $100 \mu \mathrm{L}$ of lipase (porcine pancreatic lipase, MP Biomedicals $\mathrm{LLC}$, Solon, $\mathrm{OH}$ ) for $16 \mathrm{~h}$ at $37^{\circ} \mathrm{C}$, and glycerol content was then determined by an enzymatic glycerol phosphate oxidase method (\#F6428; Sigma-Aldrich Co.). Triglyceride content was calculated based on the difference between glycerol concentrations before and after lipase digestion. Total protein content of the original homogenate was analyzed by a Coomassie blue (Bradford, 1976) colorimetric method (kit \#23236; Thermo Scientific, Pierce, Rockford, IL). To avoid potential bias introduced by differences in moisture content of liver samples, liver TG concentration was normalized by protein concentration, which is unaltered in fatty liver (Fronk et al., 1980).

The mRNA abundance of cytosolic phosphoenolpyruvate carboxykinase (cPEPCK), carnitine palmitoyltransferase 1a (CPT1a), apolipoprotein B (Apo B), and ribosomal protein subunit 9 (RPS9) in liver tissue was determined by real-time PCR. Total RNA was isolated from liver samples using a commercial kit (RNeasy Lipid Tissue Mini Kit; Qiagen Inc., Valencia, CA) and spectroscopy was used to quantify RNA (NanoDrop 1000; NanoDrop Technologies Inc., Wilmington, DE). Coding DNA was then synthesized from $2 \mu \mathrm{g}$ of total RNA using a commercial kit (High-Capacity cDNA Reverse Transcription kit; Applied Biosystems, Foster City, CA). Quantitative real-time PCR was performed in triplicate with one-twentieth of the cDNA product in the presence of $200 \mathrm{n} M$ gene-specific forward and reverse primers (Table 2) using SYBR green fluorescent detection (ABI 7500 Fast; Applied Biosystems). Messenger RNA abundance was quantified using the delta delta cycle threshold $\left(\mathrm{C}_{t}\right)$ method, with RPS9 used to normalize values. Abundance of RPS9 mRNA within liver tissue did not differ in response to treatment or across days in the study (all $P>0.50$ ), making it a valid reference gene.

Plasma was analyzed for NEFA using an enzymatic colorimetric procedure (NEFA-HR; Wako Chemicals USA Inc., Richmond, VA), glucose by a colorimetric kit (kit \#439-90901; Wako Chemicals USA Inc.), insulin by a bovine-specific sandwich ELISA (\#10-1201-01; Mercodia AB, Uppsala, Sweden), haptoglobin by a bovine-specific ELISA (kit \#2410-7 using 3,000-fold dilution; Life Diagnostics Inc., West Chester, PA), and BHBA using an enzymatic reaction (kit \#H7587-58; Pointe Scientific Inc., Canton, MI). Absorbance was read on a spectrophotometer (PowerWave XS; BioTek Instruments Inc., Winooski, VT) and calculations were 
Table 2. Primers used for quantitative real-time PCR detection of transcripts in liver tissue

\begin{tabular}{|c|c|c|c|}
\hline Gene $^{1}$ & $\begin{array}{l}\text { Accession } \\
\text { Number }^{2}\end{array}$ & $\begin{array}{l}\text { Forward primer } \\
\text { and reverse primer }\end{array}$ & $\begin{array}{l}\text { Region } \\
\text { amplified }^{3}\end{array}$ \\
\hline CPT1a & DV820520.1 & $\begin{array}{l}\text { CTTCCCATTCCGCACTTTC } \\
\text { CCATGTCCTTGTAATGAGCCA }\end{array}$ & $616-719$ \\
\hline$c P E P C K$ & NM_174737.2 & $\begin{array}{l}\text { CGAGAGCAAAGAGATACGGTGC } \\
\text { TGACATACATGGTGCGACCCT }\end{array}$ & $427-562$ \\
\hline Apo B & XM_583270.3 & $\begin{array}{l}\text { TCCTTGATTCCACATGCAGCT } \\
\text { GGTGTGCAAAGGATGCGTTAG }\end{array}$ & $8,610-8,720$ \\
\hline$R P S 9$ & DT860044.1 & $\begin{array}{l}\text { GAACAAACGTGAGGTCTGGAGG } \\
\text { ATTACCTTCGAACAGACGCCG }\end{array}$ & $233-344$ \\
\hline
\end{tabular}

${ }^{1} C P T 1 a=$ carnitine palmitoyl transferase 1a; $c P E P C K=$ cytosolic phosphoenolpyruvate carboxykinase; $A p o$ $B=$ apolipoprotein $\mathrm{B} ; R P S 9=$ ribosomal protein subunit 9 .

${ }^{2}$ From NCBI Entrez Nucleotide Database (http://www.ncbi.nlm.nih.gov/sites/entrez?db=nucleotide).

${ }^{3}$ Amplicons span an exon-exon boundary, as predicted by aligning the specified sequence to the bovine genome using Splign (http://www.ncbi.nlm.nih.gov/sutils/splign).

performed using Gen5 software (BioTek Instruments Inc.).

High-performance liquid chromatography was used to quantify plasma caffeine following the procedures of Lakritz et al. (2006). Briefly, $500 \mu \mathrm{L}$ of plasma was mixed with $500 \mu \mathrm{L}$ of $0.8 \mathrm{M}$ perchloric acid. The mixture was centrifuged at $14,000 \times g$ for $20 \mathrm{~min}$ at $21^{\circ} \mathrm{C}$, and $400 \mu \mathrm{L}$ of the clarified supernatant was transferred to an autosampler vial containing $20 \mu \mathrm{L}$ of $4 M \mathrm{NaOH}$. Vials were capped and $50 \mu \mathrm{L}$ was injected into a Discovery BIO Wide Pore C18 guard column (2 $\mathrm{cm} \times 4 \mathrm{~mm}, 5-\mu \mathrm{m}$ particle size; Supelco \#568272-U; Sigma-Aldrich Co.) and a Discovery BIO Wide Pore C18 column $(25 \mathrm{~cm} \times 4.6 \mathrm{~mm}, 5-\mu \mathrm{m}$ particle size; $\mathrm{Su}-$ pelco \#568222-U, Sigma-Aldrich). The photochemical reaction was carried out in a mobile phase consisting of $20 \mathrm{mM}$ phosphate buffer ( $\mathrm{pH} 3.0$ )-acetonitrile, 85:15 ( $\mathrm{vol} / \mathrm{vol}$ ), at a flow rate of $1 \mathrm{~mL} / \mathrm{min}$. Absorbance was read at $273 \mathrm{~nm}$ using an Acutect $500 \mathrm{UV} /$ Vis detector (\#06-653-5; Thermo Fisher Scientific, Waltham, MA).

\section{Data and Statistical Analysis}

Feeding behavior variables were calculated from logged data that included the start and end weights as well as start and end times of meals. To generate meaningful meal pattern data, feeding bouts are grouped into meals, but no broadly accepted definition exists of what constitutes a meal. Previous reports have used minimum thresholds for intermeal intervals ranging from 2 to more than 40 min (Tolkamp et al., 2000). Selecting a threshold was complicated in this study because cows started in a pen setting and then moved into tie-stalls. Therefore, approaches to data analysis were examined from 4 studies conducted by different laboratories. In these studies, minimum intermeal intervals were defined as 7.5 (Dado and Allen, 1993), 8 (Heinrichs and Conrad, 1987), 20 (Vasilatos and Wangsness, 1980), and 27.74 min (DeVries et al., 2003). For our feeding systems and housing situations, a 12-min intermeal interval was determined to be appropriate, because it is within the range of previously used thresholds and because it generated meal frequencies similar to those reported in the studies above. Therefore, meals were combined if the intermeal interval was less than $12 \mathrm{~min}$. After combining meals accordingly, any meal $<0.2 \mathrm{~kg}$ of $\mathrm{DM}$ was excluded from behavior analysis. Ruminal $\mathrm{pH}$ data were analyzed to determine mean $\mathrm{pH}$, standard deviation, amount of time spent below $\mathrm{pH} 5.8$, and area $(\mathrm{pH} \times \min )$ under $\mathrm{pH} 5.8$ for each cow each day. The threshold of 5.8 is representative of SARA according to previously established standards (Dohme et al., 2008). Caffeine elimination half-lives were determined by plotting post-infusion caffeine concentrations over time for each animal, performing an exponential regression on these values $\left(y=a \times e^{-b x}\right.$, where $a=$ intercept and $\mathrm{b}=$ slope), and using the equation half-life $=\ln 2 /$ slope (Lakritz et al., 2006). The distribution volume was determined as the dose of caffeine infused divided by the intercept.

Differences in caffeine elimination were determined using the REML procedure of JMP (version 8.0; SAS Institute Inc., Cary, NC) with the fixed effect of treatment and the random effect of cow. Other data were analyzed using mixed models with repeated measures over time (SAS 9.1; SAS Institute Inc.). Spatial power covariance structures were used to model repeated measures over time within cow for data with time points that were not equally spaced (BW, BCS, and plasma and liver variables). For data collected daily (DMI, pH, feeding behavior, and production variables), autoregressive $[A R(1)]$ covariance structures were used. Fixed effects were treatment, day relative to parturition, and treatment $\times$ day. Individual cows were treated as a random effect. Values were deemed outliers and omitted from analysis when studentized residuals were $>|3.0|$. 
After initial outlier removal, the model was repeated and studentized residuals $>|3.5|$ were deemed outliers. No more than $3 \%$ of data were removed from any single analysis. Plasma haptoglobin, insulin, liver TG, and CPT1a and Apo B mRNA data were log-transformed before analysis to achieve normal residual distributions, and the reported means and standard errors were backtransformed (Bland and Altman, 1996). Milk SCC data were transformed to somatic cell linear score (Schukken et al., 2003). Prepartum and postpartum measures were analyzed separately for DMI, water intake, and feeding behavior. Effects were declared significant at $P<0.05$, and trends are discussed at $P<0.10$.

\section{RESULTS AND DISCUSSION}

No significant difference occurred between treatments in deviation from expected calving date $(-2.0$ vs. -0.8 $\pm 1.0 \mathrm{~d}$ for the control and monensin, respectively; $P$ $=0.40$ ). Actual calving dates ranged from $10 \mathrm{~d}$ before expected calving to $7 \mathrm{~d}$ after expected calving.

\section{Feed Intake, Rumen pH, BW, Body Condition, and Milk Production}

Daily DMI is shown in Figure 1A. Intake of DM decreased before parturition and increased after parturition in both groups $(P<0.001)$, which resembles intake patterns observed in many transition cow studies (Ingvartsen and Andersen, 2000). Dry matter intake was not affected by treatment pre- or postpartum. This was surprising because other transition cow research has shown monensin to have an effect. Sauer et al. (1989) reported $1.2 \mathrm{~kg} / \mathrm{d}$ lower DMI of cows fed $30 \mathrm{~g}$ of monensin/ton of DM compared with cows receiving no monensin from 1 wk prepartum through 3 wk postpartum. Shah et al. (2008) observed a linear decrease in DMI over a complete lactation when monensin was fed at $0,7,15$, or $22 \mathrm{~g} /$ ton of DM. The reports of Sauer et al. (1989) and Shah et al. (2008) align with the $2.3 \%$ decrease in DMI concluded by meta-analysis using data from 4,445 dairy cows in all stages of lactation (Duffield et al., 2008b). In contrast, researchers found that monensin accelerated the rate of DMI increase in early lactation (Shah et al., 2008) and increased postpartum DMI in monensin-supplemented cows (Schroeder et al., 2009), although treatment means were not reported in these abstracts.

Although intakes were similar, monensin supplementation tended to decrease time between meals (Table 3 and Figure 1B; $P<0.08$ ), which is consistent with reports showing that inclusion of monensin in feedlot diets results in more consistent feed intake patterns throughout the day (Burrin et al., 1988; Erickson et al.,

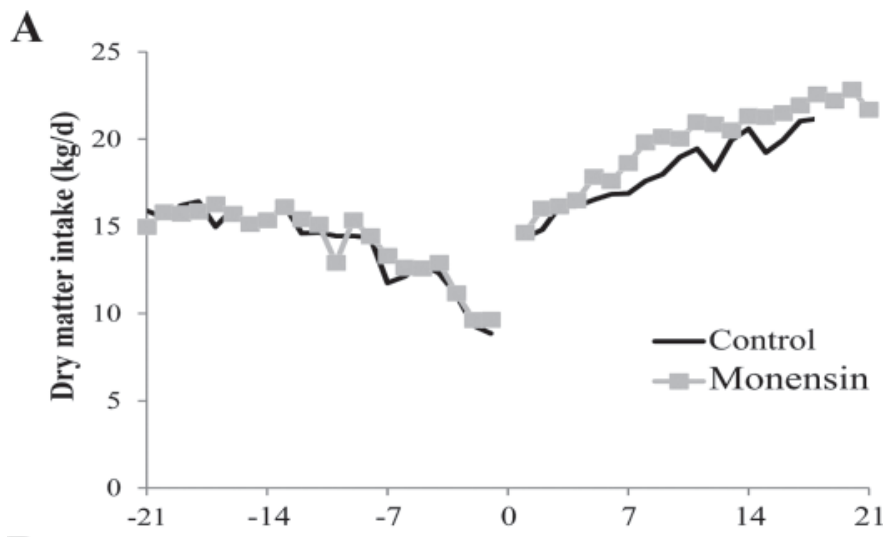

B
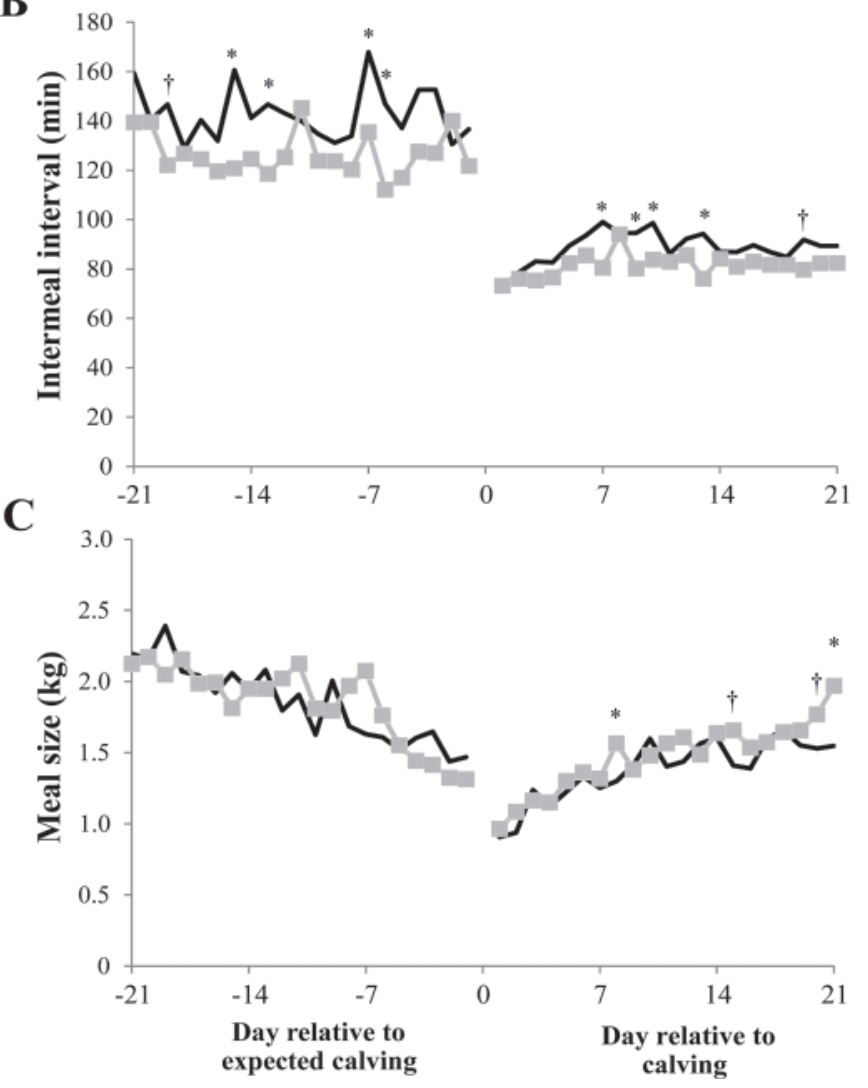

Figure 1. Dry matter intake (A), intermeal interval (B), and meal size $(\mathrm{C})$ during the experimental period. A. An effect of day pre- and postpartum was observed $(P<0.001)$; prepartum standard error of the means $=0.88$, postpartum standard error of the means $=0.87$. B. Monensin shortened intermeal interval prepartum $(P<0.03)$ and tended to shorten intermeal interval postpartum $(P<0.08)$. An effect of day postpartum was observed $(P<0.001)$; prepartum standard error of the means $=10.6$, postpartum standard error of the means $=4.77$ ( $\dagger$ denotes $P<0.10 ;{ }^{*}$ denotes $P<0.05$ ). C. An effect of day pre- and postpartum on meal size was observed $(P<0.001)$, and a treatment $\times$ day interaction was detected postpartum $(P<0.02)$; prepartum standard error of the means $=0.18$, postpartum standard error of the means $=0.09$.

2003). Even though the intermeal interval was smaller with monensin supplementation, the number of meals consumed per day and average meal duration did not 
differ between treatments. Although meal sizes were similar overall (Table 3), a treatment $\times$ day interaction was observed for postpartum meal size (effects on d 8 , 15, 20, and 21; Figure 1C). The small increase in meal frequency, coupled with similar to larger meal sizes, resulted in small, nonsignificant increases in DMI for monensin-supplemented cows during the postpartum period. Lunn et al. (2005) observed similar meal pattern results during a SARA challenge with midlactation cows, and concluded that monensin affects feeding behavior during times when rumen $\mathrm{pH}$ is low. In their study, mean ruminal $\mathrm{pH}$ was greater than the 5.9 observed in our study (Lunn et al., 2005). This implies that the cows in our study were experiencing SARA to a greater degree, and that decreased intermeal interval in fresh cows on monensin treatment may have been related to the low ruminal $\mathrm{pH}$ observed. However, monensin's effects in the current study were not dependent on the presence of SARA. Cows received a low-energy diet prepartum that should not have caused SARA, yet we still observed a shorter intermeal interval prepartum, suggesting that another mechanism must be involved in this response to monensin.

As expected, DMI was noticeably different pre- and postpartum; however, the dramatic decrease in meal length (Table 3) for postpartum cows compared with prepartum cows likely reflects differences in feeding behavior of cows in tie-stall versus pen housing rather than a true stage of production effect. DeVries et al. (2003) indirectly examined this hypothesis and found that cows housed in a freestall barn consumed dramatically fewer and larger meals than cows housed in tiestall facilities (Vasilatos and Wangsness, 1980; Dado and Allen, 1995). These 3 studies all investigated early lactation cows, and it was suggested that social interactions result in less frequent access to feed in a freestall situation, and that when cows gain access to the feed bunk, they remain there even when not eating (DeVries et al., 2003).
Daily water consumption did not differ between treatments throughout the experimental period (Table 3). Water intake of both groups was steady throughout the 21-d prepartum period. Postpartum water intake started around $80 \mathrm{~L} / \mathrm{d}$ and, as expected, increased $(P$ $<0.001)$ to approximately $115 \mathrm{~L} / \mathrm{d}$ by d 21 .

Mean ruminal $\mathrm{pH}$ and the total time per day that ruminal $\mathrm{pH}$ was below 5.8 were not affected by treatment or day $(P>0.28$; Table 4$)$ during the first $6 \mathrm{~d}$ postpartum. Some researchers suggest that a key role of monensin is to alter ruminal $\mathrm{pH}$, but that lactate needs to exceed approximately $5 \mathrm{~m} M$ for monensin to have such an effect (Osborne et al., 2004). Thus, fresh cow diets likely do not contain enough rapidly fermentable carbohydrates to promote excessive levels of lactic acid. If this is true, it would explain why monensin typically increases pH in feedlot studies (Nagaraja et al., 1981; Burrin and Britton, 1986) but few effects have been observed in dairy cattle. The lack of an effect on mean ruminal $\mathrm{pH}$ and time below 5.8 coincides with results from both transition (Mutsvangwa et al., 2002; Fairfield et al., 2007) and midlactation cow studies (Ruiz et al., 2001; Osborne et al., 2004; Mathew et al., 2011); however, these studies did not examine differences in variance of ruminal $\mathrm{pH}$. In our study, cows supplemented with monensin had a smaller standard deviation of ruminal $\mathrm{pH}$ (Figure 2; $P<0.02$ ) on d 1 postpartum, but no differences were detected beyond $\mathrm{d} 1$. The more stable ruminal $\mathrm{pH}$ in monensin-supplemented cows could have facilitated quicker adaptation of ruminal microflora to the lactation diet, and may be related to the shorter intermeal interval in this group. Notably, an effect of day was detected for area under $\mathrm{pH} 5.8(P$ $<0.03)$, with a relatively steady increase from 113 min $\times \mathrm{pH}$ units on $\mathrm{d} 1$ to $169 \pm 18 \mathrm{~min} \times \mathrm{pH}$ units on $\mathrm{d} 6$ postpartum (data not shown).

Cows receiving monensin tended to have a lower BW on $\mathrm{d} 1$ postpartum $(P<0.09)$, but no other differences were observed between treatments for BCS or BW

Table 3. Feed and water intake and feeding behavior during the experimental period

\begin{tabular}{lcccc}
\hline Item & Control & Monensin & SEM & $P$-value \\
\hline Prepartum water intake (L/d) & 20.6 & 19.1 & 1.6 & 0.48 \\
Prepartum DMI (kg/d) & 13.9 & 14.1 & 0.6 & 0.83 \\
Intermeal interval (min) & 143 & 126 & 5.0 & 0.03 \\
Meal frequency (d $\left.{ }^{-1}\right)$ & 7.57 & 8.05 & 0.36 & 0.35 \\
Meal size (kg of DM) & 1.85 & 1.85 & 0.12 & 0.99 \\
Meal length (min) & 43.4 & 42.9 & 2.3 & 0.88 \\
Postpartum water intake (L/d) & 101.6 & 101.6 & 2.7 & 0.99 \\
Postpartum DMI (kg/d) & 18.4 & 19.8 & 0.6 & 0.14 \\
Intermeal interval (min) & 88.8 & 81.4 & 2.9 & 0.08 \\
Meal frequency (d $\left.{ }^{-1}\right)$ & 13.7 & 14.8 & 0.5 & 0.12 \\
Meal size (kg of DM) & 1.38 & 1.47 & 0.06 & $0.29^{*}$ \\
Meal length (min) & 14.1 & 14.5 & 0.6 & 0.65 \\
\hline
\end{tabular}

*Treatment $\times$ day interaction detected $(P<0.02)$. 


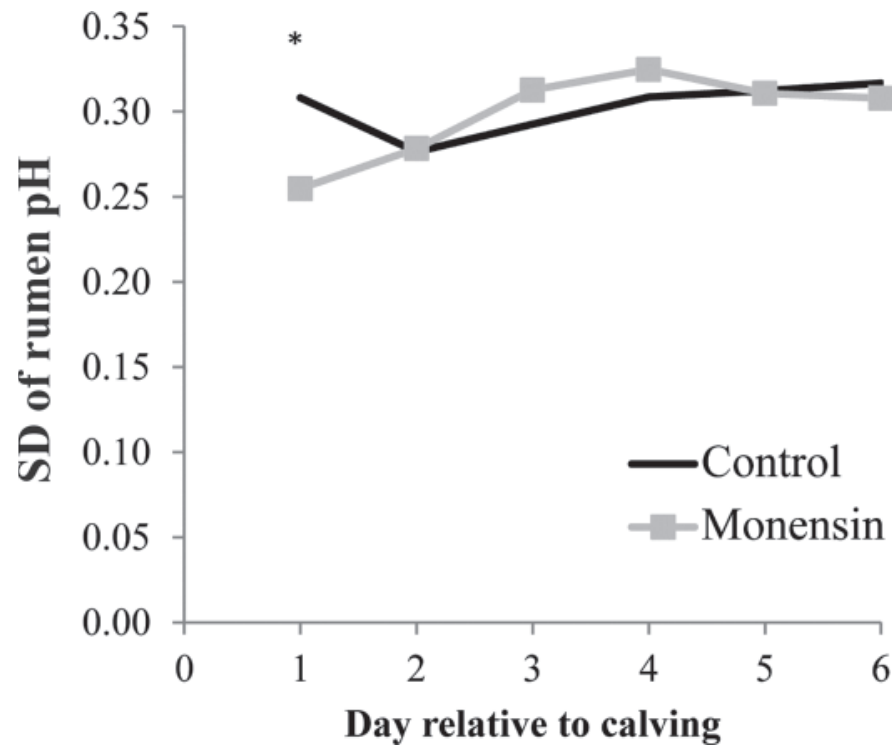

Figure 2. Standard deviation of rumen $\mathrm{pH}$ until d 7 postpartum. Monensin decreased the standard deviation of ruminal $\mathrm{pH}$ for the first day after calving $(P<0.02)$. Standard error of the means $=0.02\left(^{*}\right.$ denotes $P<0.05)$.

(data not shown). On average, cows lost 0.6 BCS units (3.3 to 2.7 ) and $110 \mathrm{~kg}$ of $\mathrm{BW}$ (767 to $657 \mathrm{~kg}$ ) during the experiment. Milk production (39.0 vs. $39.3 \pm 1.7$ $\mathrm{kg} / \mathrm{d}$ for control and monensin, respectively; $P=0.92$ ) and concentrations of fat, protein, lactose, and SNF did not differ $(P>0.18)$ between dietary treatments, but MUN was higher for monensin-supplemented cows (11.8 vs. $10.4 \pm 0.42 \mathrm{mg} / \mathrm{dL} ; P<0.02)$. No clear explanation exists for the observed effect on MUN. It has been shown that impaired liver function associated with lipid accumulation results in decreased ureagenic capability (Strang et al., 1998), but neither liver TG content nor the caffeine clearance test demonstrated dramatic effects of monensin on liver health. The MUN response could also be a result of monensin's ruminal protein sparing effect, allowing more escape protein to reach the small intestine. Duffield et al. (1998) observed a rise in blood urea nitrogen in early postpartum cows given monensin controlled-release capsules and suggested that it could be related to gluconeogenesis from nonessential AA, because the prerequisite deamination results in increased urea production. Blood urea nitrogen distributes freely into body fluids, including milk, so this proposed mechanism could help explain why MUN was higher in cows fed monensin. This is something of a paradox, however, because if monensin increases propionate supply, it may decrease the need to use AA for glucose production, potentially limiting ureagenesis. A simpler explanation is to consider that monensin-supplemented cows consumed, on average, an additional $0.23 \mathrm{~kg}$ of $\mathrm{CP} / \mathrm{d}$, with no increase in milk protein yield. If metabolizable protein supply did not limit milk protein yield in either group, then the increase in MUN for the monensin treatment was an expected response to increased CP intake.

\section{Metabolic and Endocrine Changes}

Plasma NEFA, BHBA, glucose, and insulin concentrations are displayed in Figure 3. As expected, plasma NEFA concentrations increased dramatically from 222 $\pm 80 \mu M 21 \mathrm{~d}$ before expected calving to a peak of 878 $\pm 80 \mu M$ on d 1 postpartum (Figure $3 \mathrm{~A} ; P<0.001$ ). Monensin supplementation did not significantly alter NEFA concentrations throughout the study. This was somewhat unexpected, because a meta-analysis including 24 studies with plasma NEFA data demonstrated that monensin could decrease NEFA concentration (Duffield et al., 2008a). However, the small mean response to monensin $(36.6 \mu \mathrm{Eq} / \mathrm{L})$ reported in the meta-analysis was similar to the numerical difference between treatments in this study, suggesting that the current study was simply underpowered to detect such an effect.

Monensin treatment decreased plasma BHBA over the course of the entire study (734 vs. $616 \pm 40.9 \mu M$; $P<0.05)$ with a significant effect of day $(P<0.001)$ and a treatment $\times$ day interaction $(P<0.01$; Figure 3B). Most notably, monensin significantly decreased plasma BHBA on d 4 postpartum (777 vs. $1,077 \pm 71$ $\mu M ; P<0.01)$. The effect on BHBA is not surpris-

Table 4. Rumen $\mathrm{pH}$ parameters from d 1 through 7 and results of $\mathrm{d} 7$ caffeine clearance test

\begin{tabular}{lcccl}
\hline Item & Control & Monensin & SEM & $P$-value \\
\hline Ruminal pH measures & & & & \\
Mean pH & 5.90 & 5.89 & 0.04 & 0.84 \\
SD of ruminal pH & 0.302 & 0.298 & 0.012 & $0.80^{*}$ \\
Time under pH 5.8 (min/d) & 569.3 & 583.5 & 62.1 & 0.87 \\
Area under pH 5.8 (pH $\times$ min/d) & 140.1 & 143.2 & 20.2 & 0.91 \\
Caffeine clearance measures & & & & \\
Half-life (min) & 226.3 & 207.9 & 13.5 & 0.34 \\
Distribution volume (L) & 444.0 & 445.7 & 15.0 & 0.94 \\
\hline
\end{tabular}

*Treatment $\times$ day interaction detected $(P<0.05)$. 
A

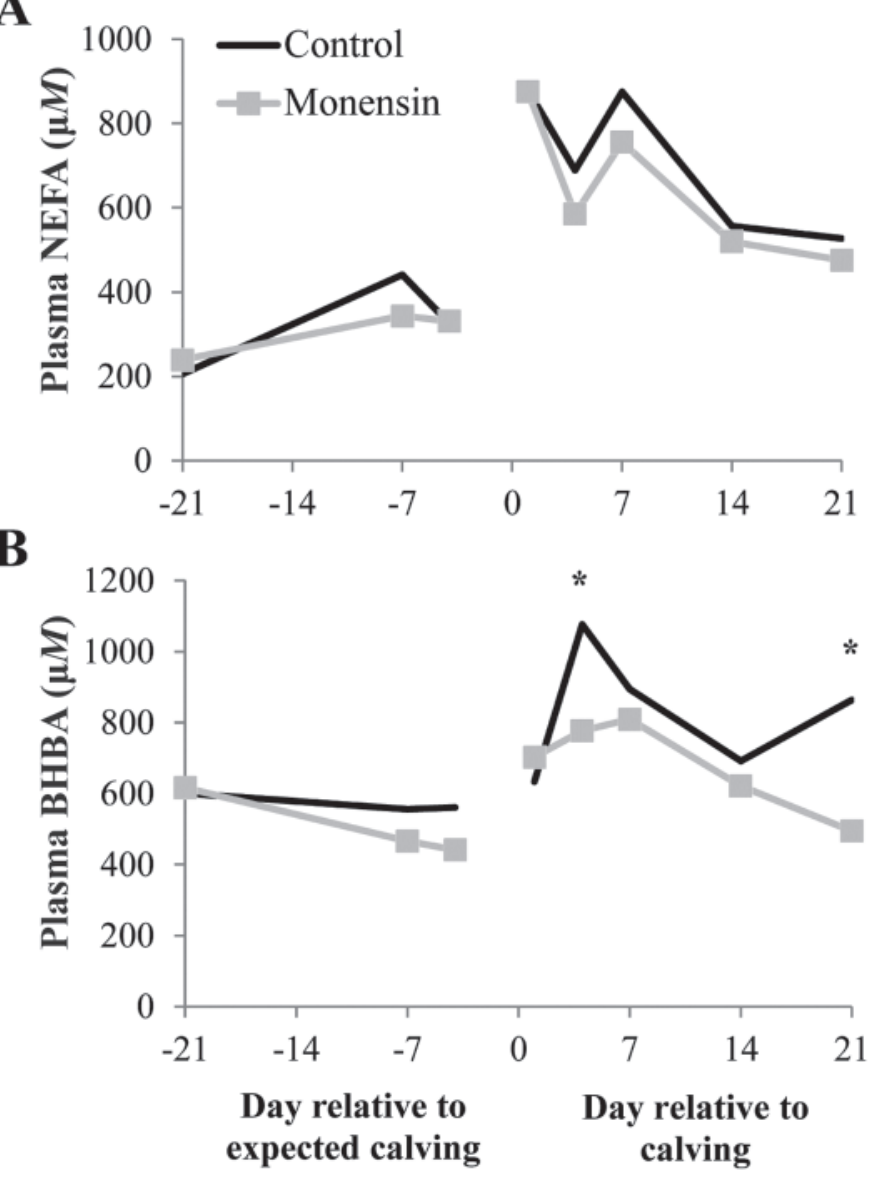

C

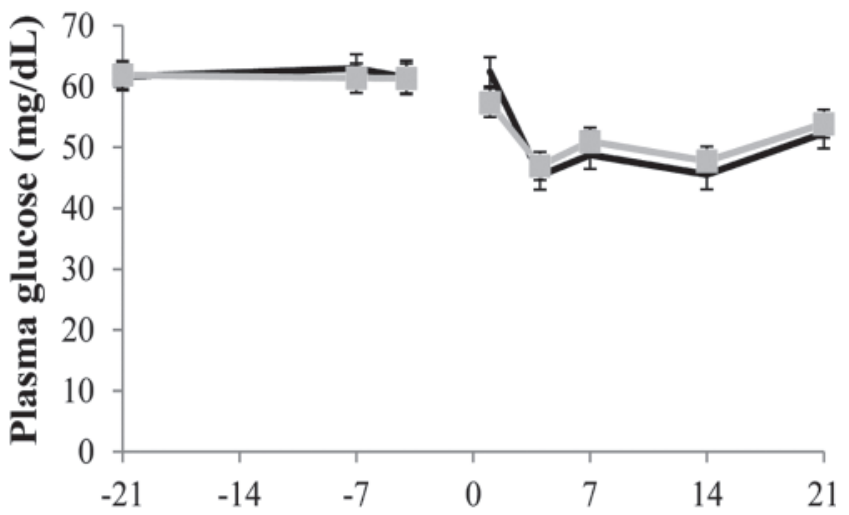

D

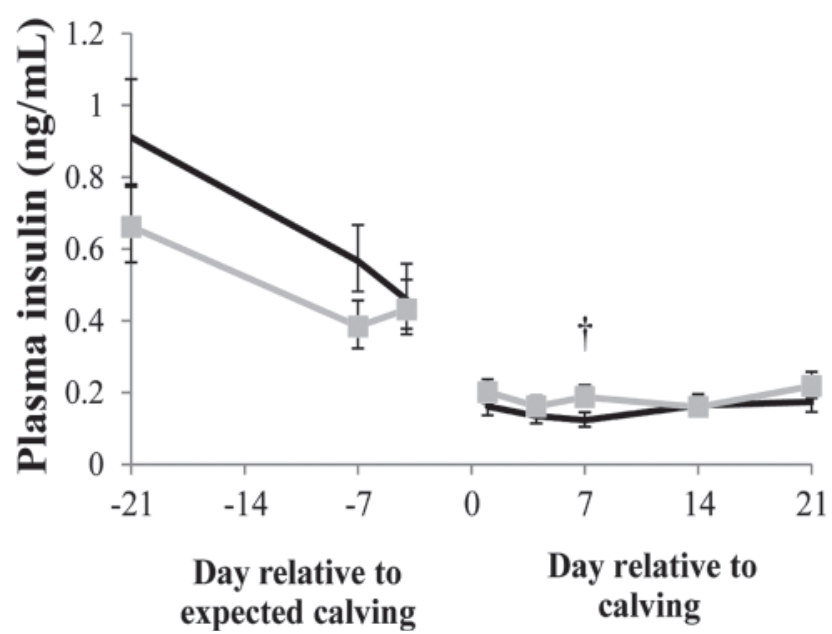

Figure 3. Plasma concentrations of NEFA (A), BHBA (B), glucose (C), and insulin (D) during the experimental period. A. No treatment effects were detected, but a day effect was observed $(P<0.001)$; standard error of the means $=84.9$. B. Effects of treatment $(P<0.05)$, day $(P$ $<0.001)$, and treatment $\times$ day interaction $(P<0.01)$ were detected; standard error of the means $=73.6(*$ denotes $P<0.05)$. C. No treatment effects were detected, but a day effect was observed $(P<0.001)$; standard error of the means $=2.38$. D. Significant effects of day $(P<0.001)$ and day $\times$ treatment interaction $(P<0.05)$ were detected. Cows receiving monensin tended to have higher plasma insulin concentrations on $\mathrm{d}$ 7 postpartum. Standard errors of the means are shown on $\mathrm{D}(\dagger$ denotes $P<0.10)$.

ing given that almost all relevant publications have reported similar decreases in BHBA (Duffield et al., 2008a). Lower BHBA concentrations are likely a result of more complete FA oxidation in the liver. Monensin can increase the supply of propionate to the liver (Van Maanen et al., 1978), which could redirect acetyl-CoA toward oxidation in the TCA cycle and away from ketone production (Allen et al., 2009).

Plasma glucose concentrations decreased after parturition in both groups $(P<0.001)$, but monensin did not affect plasma glucose concentrations pre- or postpartum. Meta-analysis indicated that monensin can increase plasma glucose concentration of transition cows, but increases were not consistently reported (Duffield et al., 2008a). Furthermore, because monensin does not always affect ruminal propionate production in transition cows (Markantonatos et al., 2009), we would not necessarily expect substrate-driven changes in gluconeogenic flux, although monensin could also alter gluconeogenic enzyme capacity (Karcher et al., 2007). Arieli et al. (2001) did not observe changes in blood glucose concentration, but observed an increase in distribution space and glucose pool size when feeding monensin to prepartum cows, suggesting increased uptake of glucose by peripheral tissues in response to monensin. If monensin does, in fact, alter clearance of plasma glucose, then plasma glucose concentration is a poor proxy for gluconeogenic flux and glucose turnover data are required to evaluate the effects of monensin on this pathway accurately. Data in this area are limited, but in one study, rate of appearance of glucose was $10 \%$ higher for monensin-supplemented cows on an equivalent DMI basis (Wheelock et al., 2009).

Overall, monensin treatment did not affect plasma insulin concentration. However, effects of day $(P<$ 
$0.001)$ and treatment $\times$ day interaction $(P<0.05)$ were significant. The treatment $\times$ day interaction showed a tendency for higher plasma insulin concentration in monensin-fed cows on $\mathrm{d} 7$ postpartum $(P<0.08)$. In the meta-analysis by Duffield et al. (2008a), data from 5 relevant reports in which plasma insulin was measured did not demonstrate an effect of monensin on insulin concentration in transition cows. Increased insulin concentration appears unlikely to be a primary mechanism by which monensin alters periparturient metabolism.

A day effect $(P<0.001)$ was detected for plasma haptoglobin concentration (Figure 4 ) as a result of an increase in the early postpartum period. Haptoglobin is an acute phase protein that increases in concentration during times of inflammation (Bionaz et al., 2007); therefore, we expected the effect of day during the transition period. Monensin did not significantly alter haptoglobin concentrations. The numerical difference between treatments on d 1 postpartum, however, seemed to correspond with the findings of Crawford et al. (2005), who reported elevated haptoglobin in diseased transition heifers given monensin. We attempted to assess whether a similar differential response could be found in our data, but were unable to conduct a valid analysis because only 1 cow on the monensin treatment had an observed health disorder before d 4 postpartum.

\section{Liver Indices}

Many metabolic fuels are oxidized or synthesized by the liver, making the health and function of this organ extremely important to early lactation dairy cows. In the present study, TG content, mRNA abundance of key genes, and caffeine clearance were used as measures of the liver's metabolic function.

Liver TG content throughout the experiment is shown in Figure 5A. All cows experienced an increase in liver TG following parturition $(P<0.001)$. A trend for a treatment $\times$ day interaction was detected $(P<$ $0.09)$, driven primarily by a tendency for increased liver TG content in monensin-treated cows on $\mathrm{d}-7(P<$ $0.09)$ and the numerical difference in the opposite direction observed on d 7 postpartum. Little data exists reporting transition cow liver TG content in response to monensin, but one group reported a tendency for animals administered monensin to have lower liver TG content $(P=0.12)$ and higher glycogen content $(P=$ 0.02) 3 wk into lactation (Zahra et al., 2006).

A major source of metabolic fuel and substrate for liver TG synthesis in transition cows are NEFA. Carnitine palmitoyl transferase 1a is important for translocating FA from the cytosol into the mitochondria, making it a central component for determining oxidative flux of FA within the liver (Drackley, 1999). If a cow fed monensin is more efficient at oxidizing FA, less liver TG accumulates, which has positive implications for transition cow health (Herdt, 1988). Results from this study indicated that liver CPT1a mRNA was greater in cows fed monensin ( 0.10 vs. $0.15 \pm 0.002$ arbitrary units, $P<0.04$; Figure 5B). The difference was driven mainly by effects on $\mathrm{d}-7$ and 1 (both $P<0.05$ ). These results suggest a novel mechanism underlying the role of monensin in improving the overall health of transition cows. This response led us to evaluate whether treatment altered the rate of liver TG accumulation during this time period. A contrast statement was used to determine whether the increase in liver TG from d -7 to $d 7$ differed by treatment. The increase in liver TG concentration was significantly greater for the control compared with monensin (412 vs. $128 \pm 83 \mathrm{mg}$ of TG/g of protein over this period, $P=0.03$ ). This differential rate of TG accumulation coincides with the treatment effects on liver CPT1a mRNA abundance. Previous findings also have suggested that monensin increases the liver's capacity to export very low density lipoprotein (Mohebbi-Fani et al. 2006). This stimulated us to measure expression of Apo, B in liver tissue from $d-7$ to 7 , but treatment had no effect on Apo B mRNA abundance during this period $(P=0.42)$. Expression of Apo B was upregulated over this time period $(0.18,0.35$, and $1.13 \pm 0.28$ arbitrary units for $\mathrm{d}-7,1$, and 7, respectively). Expression of Apo B appeared to adapt to the increased TG synthesis in the liver of these transition cows, but monensin did not regulate lipoprotein secretion through Apo B transcription in this experiment.

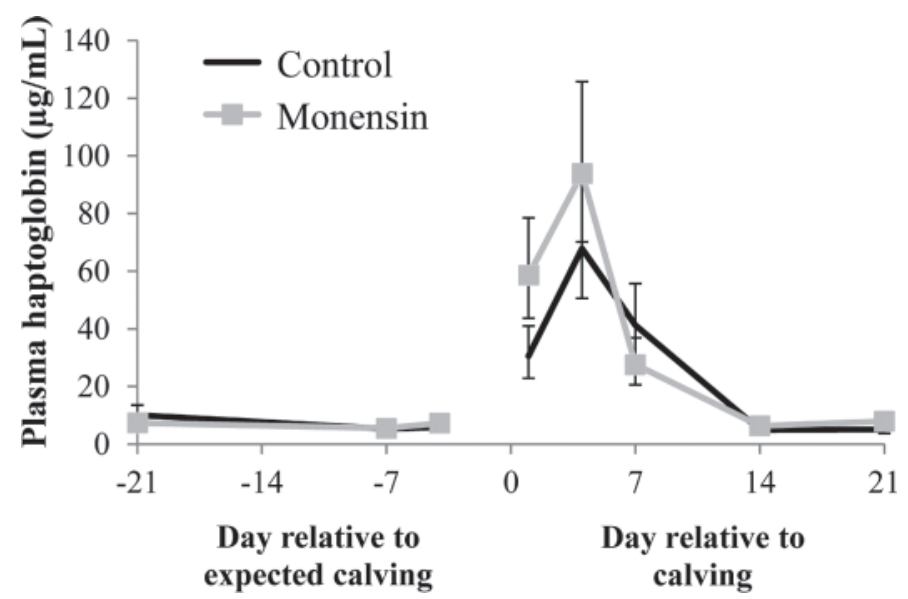

Figure 4. Plasma concentrations of haptoglobin during the experimental period. No treatment differences were detected; however, an effect of day was detected $(P<0.001)$. Standard errors of the means are shown on the graph. 
$\mathbf{A}$

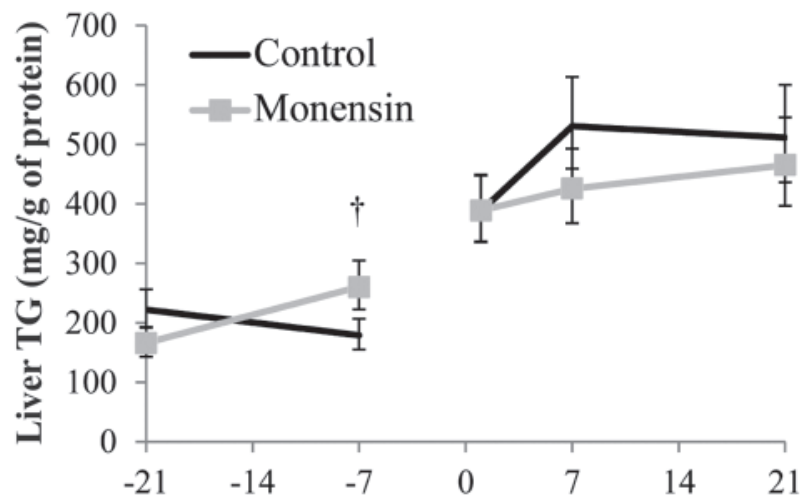

B

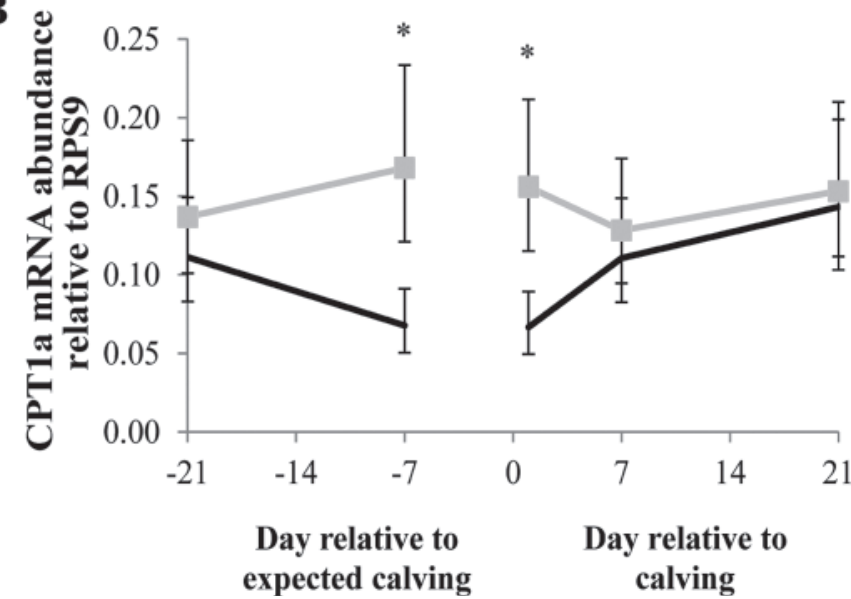

Figure 5. Triglyceride (TG) content (A) and mRNA abundance of carnitine palmitoyl transferase 1a (CPT1a; B) in liver tissue during the experimental period. A. A tendency for a treatment $\times$ day effect was detected $(P<0.09)$. Liver TG content increased in both groups during the study period $(P<0.001)$; standard errors of the means are shown on the graph ( $\dagger$ denotes $P<0.10)$. B. Monensin significantly increased abundance of CPT1a relative to the control gene ribosomal protein subunit 9 (RPS9; $P<0.04$ ); standard errors of the means are shown on the graph (* denotes $P<0.05)$.

The evidence that monensin lowers transition cow plasma ketone concentrations is substantial (Duffield et al., 2008a), but most reports referenced in the metaanalysis of Duffield et al. (2008a) explain the effect on ketones through increased supply of propionate for hepatic gluconeogenesis. To our knowledge, our report is the first to consider the effects of monensin on abundance of CPT1a in dairy cows, and suggests that monensin has a positive effect on lipid metabolism in the liver. Although $\beta$-oxidation of FA can result in either complete oxidation of acetyl-CoA or ketone production, increased CPT1a abundance could benefit liver function because increased mitochondrial oxidation could 1) limit TG synthesis, 2) decrease reliance on peroxisomal oxidation with its subsequent production of reactive oxygen species, and 3) prevent accumulation of lipid metabolites that may impair metabolic function (FA-CoA, ceramides, and peroxides, among others). Nevertheless, these findings should not be over-interpreted because our results are limited to the transcript level, and we did not observe obvious corresponding decreases in liver TG content or hepatic inflammation (as measured by plasma haptoglobin concentration).

The liver is the primary site for gluconeogenesis, and cPEPCK is thought to be a rate-determining enzyme for hepatic gluconeogenesis from propionate, lactate, and AA (Greenfield et al., 2000). The relative abundance of liver cPEPCK mRNA differed across day of study $(P<0.02)$, but was not different between treatments. The slight change through the transition period (an $85 \%$ increase from d 1 to 21 postpartum) is consistent with previous reports (Greenfield et al., 2000; Hartwell et al., 2001); however, when monensin was fed to transition cows, cPEPCK expression increased (Karcher et al., 2007), so it was surprising that no differences were detected in this study. Because cPEPCK is one of several rate-determining gluconeogenic enzymes, this is consistent with the lack of treatment effect on plasma glucose concentration, although mRNA abundance is not a measure of enzyme activity and plasma glucose concentration is not a measure of gluconeogenic flux.

Liver diseases, including fatty liver, decrease activity of the cytochrome P450 (CYP450) enzyme complex (Frye et al., 2006), and activity of CYP450 can serve as an index of normal liver function. We assessed metabolism of caffeine because it is metabolized by CYP 450 and has few side effects when administered at low doses (Lakritz et al., 2006). Results of the caffeine challenge tests are shown in Table 4. Caffeine elimination half-life was 226 and $208 \pm 13.5$ min for control and monensin cows, respectively, and no differences were detected $(P$ $=0.34$ ). The volume of distribution of caffeine also was calculated, and similar results across treatments suggest no bias in administering the caffeine dose; thus, our results do not indicate that CYP450 activity was enhanced or impaired by monensin treatment. Reports of caffeine clearance in dairy cows are limited. DeGraves et al. (1995) examined hepatic function of later-lactation dairy cows and reported an average elimination half-life of $228 \mathrm{~min}$ (range was 156 to $414 \mathrm{~min}$ ), which was remarkably similar to our results. In the current study, caffeine elimination half-life also was correlated with log-transformed plasma haptoglobin concentration $(P=0.03, \mathrm{r}=0.41)$, similar to results from a separate study conducted in our laboratory (Morey et al., 2011). These positive correlations between markers of impaired liver function and liver inflammation are consistent with their utility as gauges of metabolic health in transition cows. 
Table 5. Incidence of health disorders during the experimental period

\begin{tabular}{lcc}
\hline Disorder $^{1}$ & Control & Monensin \\
\hline Retained placenta & 0 & 1 \\
Fever $>39.4^{\circ} \mathrm{C}$ & 5 & 7 \\
Ketosis & 5 & 3 \\
Hypocalcemia & 2 & 0 \\
Metritis & 1 & 1 \\
Mastitis & 7 & 5 \\
Displaced abomasum & 2 & 1 \\
Other digestive disorder & 4 & 3 \\
One or more disorders $^{2}$ & 12 & 11 \\
Dystocia $^{2}$ & 3 & 5 \\
\hline
\end{tabular}

${ }^{1}$ No differences were detected between treatment groups $(P>0.10)$ using Fisher's exact test.

${ }^{2}$ Dystocia was defined as a calving difficulty score $>1$; calving scores were defined according to Dairy Records Management Systems (2010).

\section{Management and Health}

The incidences of health disorders are shown in Table 5. No differences were found between treatment groups. Because only 32 experimental units were used for this study, detecting differences in disease incidence would have been difficult. A more powerful assessment of the effects of monensin on cow health is the meta-analysis conducted by Duffield et al. (2008c). These researchers combined data from 16 papers; overall, monensin significantly decreased the relative risk of ketosis, displaced abomasum, and mastitis. The BHBA response observed in our study is consistent with the means reported in the meta-analysis (Duffield et al., 2008c). Therefore, monensin likely lowers the risk of diseases such as ketosis and displaced abomasa because these diseases are related to energy status, although our study lacked statistical power to detect these differences.

\section{CONCLUSIONS}

In this first report of monensin's effects on feeding behavior combined with ruminal $\mathrm{pH}$ dynamics in transition cows, monensin increased meal frequency and minimized ruminal $\mathrm{pH}$ variance in the first day after cows changed to a lactation ration. Monensin supplementation also significantly increased liver mRNA abundance of CPT1a, a key mediator of liver mitochondrial FA oxidation, and decreased the rate of liver TG accumulation in the 2 wk around parturition. Consistent with previous results, monensin significantly decreased peak plasma BHBA concentrations in postpartum cows, but did not alter concentrations of plasma NEFA, glucose, or insulin in the postpartum period. Despite the observed beneficial effects on metabolism, no significant effects on milk production or disease incidence were detected.

\section{ACKNOWLEDGMENTS}

This paper is contribution no. 11-386-J from the Kansas Agricultural Experiment Station (Manhattan). The authors thank Elanco Animal Health (Greenfield, IN) for partially funding this research and especially for providing financial assistance to build feeding behavior systems at the Kansas State University Dairy Unit (Manhattan). We also thank contributors at Kansas State University: Michael Scheffel, Cheryl Armendariz, and all of the undergraduate and graduate students that helped with feeding and data collection, particularly Jaymelynn Farney, Claire Legallet, and Michelle Sullivan. We are grateful to Marina von Keyserlingk and her laboratory group at the University of British Columbia (Vancouver, BC, Canada) for technical assistance with feeding behavior data processing.

\section{REFERENCES}

Aiello, R. J., and L. E. Armentano. 1987. Effects of volatile fatty acids on propionate metabolism and gluconeogenesis in caprine hepatocytes. J. Dairy Sci. 70:2504-2510.

Allen, M. S., B. J. Bradford, and M. Oba. 2009. Board-invited review: The hepatic oxidation theory of the control of feed intake and its application to ruminants. J. Anim. Sci. 87:3317-3334.

Arieli, A., J. E. Vallimont, Y. Aharoni, and G. A. Varga. 2001. Monensin and growth hormone effects on glucose metabolism in the prepartum cow. J. Dairy Sci. 84:2770-2776.

Bertics, S. J., R. R. Grummer, C. Cadorniga-Valino, and E. E. Stoddard. 1992. Effect of prepartum dry matter intake on liver triglyceride concentration and early lactation. J. Dairy Sci. 75:19141922

Bionaz, M., E. Trevisi, L. Calamari, F. Librandi, A. Ferrari, and G. Bertoni. 2007. Plasma paraoxonase, health, inflammatory conditions, and liver function in transition dairy cows. J. Dairy Sci. 90:1740-1750.

Bland, J. M., and D. G. Altman. 1996. Statistics notes: Transformations, means, and confidence intervals. BMJ 312:1079.

Bradford, M. M. 1976. A rapid and sensitive method for the quantitation of microgram quantities of protein utilizing the principle of protein-dye binding. Anal. Biochem. 72:248-254.

Burrin, D. G., and R. A. Britton. 1986. Response to monensin in cattle during subacute acidosis. J. Anim. Sci. 63:888-893.

Burrin, D. G., R. A. Stock, and R. A. Britton. 1988. Monensin level during grain adaption and finishing performance in cattle. J. Anim. Sci. 66:513-521.

Crawford, R. G., K. E. Leslie, R. Bagg, C. P. Dick, and T. F. Duffield. 2005. The impact of controlled release capsules of monensin on postcalving haptoglobin concentrations in dairy cattle. Can. J. Vet. Res. 69:208-214.

Dado, R. G., and M. S. Allen. 1993. Continuous computer acquisition of feed and water intakes, chewing, reticular motility, and ruminal pH of cattle. J. Dairy Sci. 76:1589-1600.

Dado, R. G., and M. S. Allen. 1995. Intake limitations, feeding behavior, and rumen function of cows challenged with rumen fill from dietary fiber or inert bulk. J. Dairy Sci. 78:118-133.

Dairy Records Management Systems. 2010. DHI glossary. Accessed Dec. 3, 2010. http://www.drms.org/PDF/materials/glossary.pdf.

DeGraves, F. J., D. C. Ruffin, S. H. Duran, J. S. Spano, E. M. Whatley, J. Schumacher, and M. G. Riddell. 1995. Pharmacokinetics of caffeine in lactating dairy cows. Am. J. Vet. Res. 56:619-622.

DeVries, T. J., M. A. G. von Keyserlingk, D. M. Weary, and K. A Beauchemin. 2003. Measuring the feeding behavior of lactating dairy cows in early to peak lactation. J. Dairy Sci. 86:3354-3361. 
Dohme, F., T. J. DeVries, and K. A. Beauchemin. 2008. Repeated ruminal acidosis challenges in lactating dairy cows at high and low risk for developing acidosis: Ruminal pH. J. Dairy Sci. 91:35543567.

Dohoo, I. R., J. Smith, S. Andersen, D. F. Kelton, and S. Godden. 2011. Diagnosing intramammary infections: Evaluation of definitions based on a single milk sample. J. Dairy Sci. 94:250-261.

Drackley, J. K. 1999. Biology of dairy cows during the transition period: The final frontier? J. Dairy Sci. 82:2259-2273.

Duffield, T. F., A. R. Rabiee, and I. J. Lean. 2008a. A meta-analysis of the impact of monensin in lactating dairy cattle. Part 1. Metabolic effects. J. Dairy Sci. 91:1334-1346.

Duffield, T. F., A. R. Rabiee, and I. J. Lean. 2008b. A meta-analysis of the impact of monensin in lactating dairy cattle. Part 2. Production effects. J. Dairy Sci. 91:1334-1346.

Duffield, T. F., A. R. Rabiee, and I. J. Lean. 2008c. A meta-analysis of the impact of monensin in lactating dairy cattle. Part 3. Health and reproduction. J. Dairy Sci. 91:2328-2341.

Duffield, T. F., D. Sandals, K. E. Leslie, K. Lissemore, B. W. McBride, J. H. Lumsden, P. Dick, and R. Bagg. 1998. Effect of prepartum administration of monensin in a controlled-release capsule on postpartum energy indicators in lactating dairy cows. J. Dairy Sci. $81: 2354-2361$

Erickson, G. E., C. T. Milton, K. C. Fanning, R. J. Cooper, R. S. Swingle, J. C. Parrott, G. Vogel, and T. J. Klopfenstein. 2003. Interaction between bunk management and monensin concentration during an acidosis challenge with feedlot cattle. J. Anim. Sci 81:2869-2879.

Fairfield, A. M., J. C. Plaizier, T. F. Duffield, M. I. Lindinger, R. Bagg, P. Dick, and B. W. McBride. 2007. Effects of prepartum administration of a monensin controlled release capsule on rumen $\mathrm{pH}$, feed intake, and milk production of transition dairy cows. J. Dairy Sci. 90:937-945.

Fronk, T. J., L. H. Schultz, and A. R. Hardie. 1980. Effect of dry period overconditioning on subsequent metabolic disorders and performance of dairy cows. J. Dairy Sci. 63:1080-1090.

Frye, R. F., N. K. Zgheib, G. R. Matzke, D. Chaves-Gnecco, M. Rabinovitz, O. S. Shaikh, and R. A. Branch. 2006. Liver disease selectively modulates cytochrome P450-mediated metabolism. Clin. Pharmacol. Ther. 80:235-245.

Green, B. L., B. W. McBride, W. D. Sandals, K. E. Leslie, R. Bagg, and P. Dick. 1999. The impact of the monensin controlled-release capsule upon subclinical ketosis in the transition dairy cow. J. Dairy Sci. 82:333-342.

Greenfield, R. B., M. J. Cecava, and S. S. Donkin. 2000. Changes in mRNA expression for gluconeogenic enzymes in liver of dairy cattle during the transition to lactation. J. Dairy Sci. 83:1228-1236.

Grummer, R. R. 1995. Impact of changes in organic nutrient metabolism on feeding the transition dairy cow. J. Anim. Sci. 73:28202833 .

Hartwell, J. R., M. J. Cecava, and S. S. Donkin. 2001. Rumen undegradable protein, rumen-protected choline and mRNA expression for enzymes in gluconeogenesis and ureagenesis in periparturient dairy cows. J. Dairy Sci. 84:490-497.

Heinrichs, A. J., and H. R. Conrad. 1987. Measuring feed intake patterns and meal size of lactating dairy cows. J. Dairy Sci. 70:705711.

Herdt, T. H. 1988. Fatty liver in dairy cows. Vet. Clin. North Am. Food Anim. Pract. 4:269-287.

Ingvartsen, K. L., and J. B. Andersen. 2000. Integration of metabolism and intake regulation: A review focusing on periparturient animals. J. Dairy Sci. 83:1573-1597.

Karcher, E. L., M. M. Pickett, G. A. Varga, and S. S. Donkin. 2007. Effect of dietary carbohydrate and monensin on expression of gluconeogenic enzymes in liver of transition dairy cows. J. Anim. Sci. 85:690-699.

Kelton, D. F., K. D. Lissemore, and R. E. Martin. 1998. Recommendations for recording and calculating the incidence of selected clinical diseases of dairy cattle. J. Dairy Sci. 81:2502-2509.

Lakritz, J., J. R. Middleton, D. E. Anderson, D. R. Linden, R. A Sams, R. K. Tessman, and J. W. Tyler. 2006. Pharmacokinetics of intravenously administered caffeine in healthy alpacas (Lama pacos) and llamas (Lama glama). Am. J. Vet. Res. 67:1063-1069.

Lunn, D. E., T. Mutsvangwa, N. E. Odongo, T. F. Duffield, R. Bagg, P. Dick, G. Vessie, and B. W. McBride. 2005. Effect of monensin on meal frequency during sub-acute ruminal acidosis in dairy cows. Can. J. Anim. Sci. 85:247-249.

Markantonatos, X., Y. Aharoni, L. F. Richardson, and G. A. Varga. 2009. Effects of monensin on volatile fatty acid metabolism in periparturient dairy cows using compartmental analysis. Anim. Feed Sci. Technol. 153:11-27.

Mathew, B., M. L. Eastridge, E. R. Oelker, J. L. Firkins, and S. K. Karnati. 2011. Interactions of monensin with dietary fat and carbohydrate components on ruminal fermentation and production responses by dairy cows. J. Dairy Sci. 94:396-409.

Mohebbi-Fani, M., S. Nazifi, S. S. Shekarforoush, and M. Rahimi. 2006. Effect of monensin on serum lipoproteins, triglycerides, cholesterol and total lipids of periparturient dairy cows. Vet. Res. Commun. 30:7-17.

Morey, S. D., L. K. Mamedova, D. E. Anderson, C. K. Armendariz, E. C. Titgemeyer, and B. J. Bradford. 2011. Effects of encapsulated niacin on metabolism and production of periparturient dairy cows. J. Dairy Sci. 94:5090-5104.

Mutsvangwa, T., J. P. Walton, J. C. Plaizier, T. F. Duffield, R. Bagg, P. Dick, G. Vessie, and B. W. McBride. 2002. Effects of a monensin controlled-release capsule or premix on attenuation of subacute ruminal acidosis in dairy cows. J. Dairy Sci. 85:3454-3461.

Nagaraja, T. G., T. B. Avery, E. E. Bartley, S. J. Galitzer, and A. D. Dayton. 1981. Prevention of lactic acidosis in cattle by lasalocid or monensin. J. Anim. Sci. 53:206-216.

Nagaraja, T. G., C. J. Newbold, C. J. Van Nevel, and D. I. Demeyer. 1997. Manipulation of ruminal fermentation. Pages 542-545 in The Rumen Microbial Ecosystem. 2nd ed. P. N. Hobson and C. S. Stewart, ed. Blackie Academic \& Professional, London, UK.

NRC. 2001. Nutrient Requirements of Dairy Cattle. 7th rev. ed. Natl. Acad. Sci., Washington, DC.

Osborne, J. K., T. Mutsvangwa, O. Alzahal, T. F. Duffield, R. Bagg, P. Dick, G. Vessie, and B. W. McBride. 2004. Effects of monensin on ruminal forage degradability and total tract diet digestibility in lactating dairy cows during grain-induced subacute ruminal acidosis. J. Dairy Sci. 87:1840-1847.

Petersson-Wolfe, C. S., K. E. Leslie, T. Osborne, B. W. McBride, R. Bagg, G. Vessie, P. Dick, and T. F. Duffield. 2007. Effect of monensin delivery method on dry matter intake, body condition score, and metabolic parameters in transition dairy cows. J. Dairy Sci. 90:1870-1879.

Ruiz, R., G. L. Albrecht, L. O. Tedeschi, G. Jarvis, J. B. Russell, and D. G. Fox. 2001. Effect of monensin on the performance and nitrogen utilization of lactating dairy cows consuming fresh forage. J. Dairy Sci. 84:1717-1727.

Sauer, F. D., J. K. G. Kramer, and W. J. Cantwell. 1989. Antiketogenic effects of monensin in early lactation. J. Dairy Sci. 72:436-442.

Schroeder, G. F., B. D. Strang, M. A. Shah, M. A. Messman, and H. B. Green. 2009. Effects of increasing levels of monensin on dairy cows in early lactation. J. Dairy Sci. 92(E-Suppl. 1):284-285. (Abstr.)

Schukken, Y. H., D. J. Wilson, F. Welcome, L. Garrison-Tikofsky, and R. N. Gonzalez. 2003. Monitoring udder health and milk quality using somatic cell counts. Vet. Res. 34:579-596.

Shah, M. A., G. Schroeder, B. D. Strang, and H. B. Green. 2008. Effect of monensin concentration on dry matter intake during the transition period of lactating dairy cows. J. Dairy Sci. 91(E Suppl. 1):268-269. (Abstr.)

Starke, A., A. Haudum, R. Busche, M. Beyerback, S. Dänicke, and J. Rehage. 2010. Technical note: Analysis of total lipid and triacylglycerol content in small liver biopsy samples in cattle. J. Anim. Sci. 88:2741-2750.

Stephenson, K. A., I. J. Lean, M. L. Hyde, M. A. Curtis, J. K. Garvin, and L. B. Lowe. 1997. Effects of monensin on the metabolism of periparturient dairy cows. J. Dairy Sci. 80:830-837.

Stock, R. A., S. B. Laudert, W. W. Stroup, E. M. Larson, J. C. Parrott, and R. A. Britton. 1995. Effect of monensin and monensin 
and tylosin combination on feed intake variation of feedlot steers. J. Anim. Sci. 73:39-44.

Strang, B. D., S. J. Bertics, R. R. Grummer, and L. E. Armentano. 1998. Effect of long-chain fatty acids on triglyceride accumulation, gluconeogenesis, and ureagenesis in bovine hepatocytes. J. Dairy Sci. 81:728-739.

Tolkamp, B. J., D. P. N. Schweitzer, and I. Kyriazakis. 2000. The biologically relevant unit for the analysis of short-term feeding behavior of dairy cows. J. Dairy Sci. 83:2057-2068.

Tyrrell, H. F., and J. T. Reid. 1965. Prediction of the energy value of cow's milk. J. Dairy Sci. 48:1215-1223.

Van Maanen, R. W., J. H. Herbein, A. D. McGilliard, and J. W. Young. 1978. Effects of monensin on in vivo rumen propionate production and blood glucose kinetics in cattle. J. Nutr. 108:1002-1007.
Vasilatos, R., and P. J. Wangsness. 1980. Feeding behavior of lactating dairy cows as measured by time-lapse photography. J. Dairy Sci. 63:412-416.

Wheelock, J. B., S. R. Sanders, M. D. O'Brien, C. E. Moore, H. B. Green, M. R. Waldron, R. P. Rhoads, and L. H. Baumgard. 2009 Effects of heat stress and monensin on production and metabolism in lactating Holstein cows. J. Dairy Sci. 92(E-Suppl. 1):333-334. (Abstr.)

Zahra, L. C., T. F. Duffield, K. E. Leslie, T. R. Overton, D. Putnam, and S. J. LeBlanc. 2006. Effects of rumen-protected choline and monensin on milk production and metabolism of periparturient cows. J. Dairy Sci. 89:4808-4818. 